\title{
Taxation and Budget Reform Commission (TBRC) Statutory Recommendation: Just Value Assessment of Real and Tangible Personal Property and Burden of Proof ${ }^{1}$
}

Rodney L. Clouser ${ }^{2}$

A series of 16 fact sheets has been written on statutory and constitutional proposals adopted by the Taxation and Budget Reform Commission (TBRC). The publications in this series can be accessed at http://edis.ifas.ufl.edu. Fact sheets FE733 through FE741 address statutory changes and fact sheets FE742 through FE748 address constitutional amendments. These fact sheets should not be considered as an all-inclusive assessment of the statutory or constitutional changes recommended by the Taxation and Budget Reform Commission. Some details of proposed changes may not have been discussed due to space limitations. These fact sheets are not intended as a replacement for personal knowledge about actual or proposed changes but are a guide to inform the public on the issues.

\section{Introduction}

The Taxation and Budget Reform Commission (TBRC) has made a statutory recommendation to the Florida Legislature concerning just value assessment of real and tangible personal property and burden of proof of accurately assessing the property. This recommended statutory change shifts the burden of proof of correct assessment of real and tangible personal property from the taxpayer to the elected property appraiser. Currently, taxpayers can only overturn an "assessment based on a preponderance of the evidence that the assessment exceeds just value."

\section{Current Situation Compared with Recommendations}

Presently, the elected county property appraiser is charged with assessing property according to a just value (market value) concept specified in Florida Statute 193.011. The statute identifies several criteria that the property appraiser should apply in determining just value. A basic summary of those criteria are:

1. The current cash value of the property that a willing purchaser would pay for the property less realistic fees or costs.

1. This is EDIS document FE736, a publication of the Food and Resource Economics Department, Florida Cooperative Extension Service, Institute of Food and Agricultural Sciences, University of Florida, Gainesville, FL. Published July 2008. Please visit the EDIS website at http://edis.ifas.ufl.edu.

2. Rodney L. Clouser, professor and extension public policy specialist of the Food and Resource Economics Department, Florida Cooperative Extension Service, Institute of Food and Agricultural Sciences, University of Florida, Gainesville, FL.

The Institute of Food and Agricultural Sciences (IFAS) is an Equal Opportunity Institution authorized to provide research, educational information and other services only to individuals and institutions that function with non-discrimination with respect to race, creed, color, religion, age, disability, sex, sexual orientation, marital status, national origin, political opinions or affiliations. U.S. Department of Agriculture, Cooperative Extension Service, University of Florida, IFAS, Florida A. \& M. University Cooperative Extension Program, and Boards of County Commissioners Cooperating. Larry Arrington, Dean 
2. The highest and best use of the property in the immediate future, as well as the current use of the property. Other factors that are to be taken into consideration include any state or local limitations, historical preservation ordinances or regulations, etc.

3. The location of the property.

4. The size of the property.

5. The price of the property and any replacement value of any improvements on the property.

6 . The condition of the property.

7. Income earned or generated from the property.

8. Net proceeds generated from the sale of the property after deduction of reasonable fees and costs.

The just value recommendation of the TBRC specifically addresses criteria number two ("The highest and best use of the property in the immediate future, as well as the current use of the property. Other factors that are to be taken into consideration include any state or local limitations, historical preservation ordinances or regulations, etc").

The language recommended by the TBRC states that "the property appraiser shall have the burden of proving by a preponderance of the evidence that the assessment established by the value adjustment board is less than just value if the property appraiser's assessment is determined to be erroneous." One piece of data used to support this recommendation was the declining number of taxpayers who were successful in challenging the value placed on the property by their county property appraiser. In Florida, taxpayers can challenge the value placed on their property through a local Value Adjustment Board (VAB). The Value Adjustment Board for each county has traditionally been comprised of three members of the county commission and two members of the school board (Florida Statute 194.015) and can uphold or overturn the value placed on the property by the appraiser. Legislation passed during the 2008 legislative session amended the composition of the VAB to two county commissioners, one school board member, and two citizens at large. In 1994, about
$40 \%$ of the taxpayers who challenged the property appraisers assessment were successful in their appeals. Since 2003, the number of successful appeals has dropped to below $20 \%$.

The TBRC has suggested additional criteria for establishing just value. Explicit recommendations include the legally permissible use(s) of property, zoning changes, concurrency requirements, and permits required to realize the highest and best use of the property. Other factors required to be used by the property appraiser include physical deterioration and functional obsolescence of the property. Finally, it was the recommendation of the TBRC that the statutory changes become effective for 2009 assessments.

\section{Impact of Proposed Statutory Change}

The impact of the proposed statutory change is unknown. If property owners are successful in lowering their assessments, it should result in a lower tax burden for them. However, local units of government could offset any decrease in assessment with higher millage rates. Lowering any individual's property assessment, while keeping everything else equal for all other taxpayers, would result in those not having their assessment lowered paying a relatively higher share of the tax burden. It is not anticipated that the increase in tax burden would be large.

The recommendation by the TBRC has two distinct requirements for the property appraiser: (1) the property appraiser must be able to demonstrate correct application of the statutory requirements in deriving just value and (2) "the property appraiser shall have the burden of proving by a preponderance of the evidence that the assessment established by the value adjustment board is less than just value if the property appraiser's assessment is determined to be erroneous." It is uncertain if these changes will alter the number and percentage of successful appeals by property owners to the Value Adjustment Board.

\section{Summary}

Although the statutory recommendations have been made by the TBRC, and in some instances with specific dates to become effective, the Florida 
Legislature and the Governor are not bound to the effective dates or the recommendations. Before these recommendations become law, they require approval of both the Florida Senate and House, and approval by the Governor. Citizens interested in the specific recommendations will need to follow the progress of the issue through the legislative process.

Additionally, there is no time limit for action by the legislature on the TBRC recommendations and they can be introduced in any future legislative session after initial submission by the TBRC.

\section{References}

Florida Taxation and Budget Reform Commission. 2008. An act relating to ad valorem taxation. TBRC, Tallahassee, FL (April). http://www.floridatbrc.org/pdf/SR0013_1stEng.pdf

Florida Taxation and Budget Reform Commission. 2008. SR 13 Staff Analysis and Economic Impact Statement. TBRC, Tallahassee, FL (April).

http://www.floridatbrc.org/pdf/

SR13StyleDraftingFinal.pdf

Florida Taxation and Budget Reform Commission. 2008. Transmittal letter. TBRC, Tallahassee, FL (April).

http://www.floridatbrc.org/pdf/ 3_28_08TransmittalLetterSR13.pdf

State of Florida. 2008. Factors to consider in deriving just valuation. StateplaceFlorida Statute 193.011. Florida Legislature, Tallahassee, FL. http://www.flsenate.gov/Statutes/ index.cfm?App_mode=Display_Statute\&URL=Ch01 93/ part01.htm \&StatuteYear $=2007 \&$ Title $=\% 2 \mathrm{D} \% 3 \mathrm{E} 2007$ \%2D\%3EChapter\%20193\%2D\%3EPart\%20I 